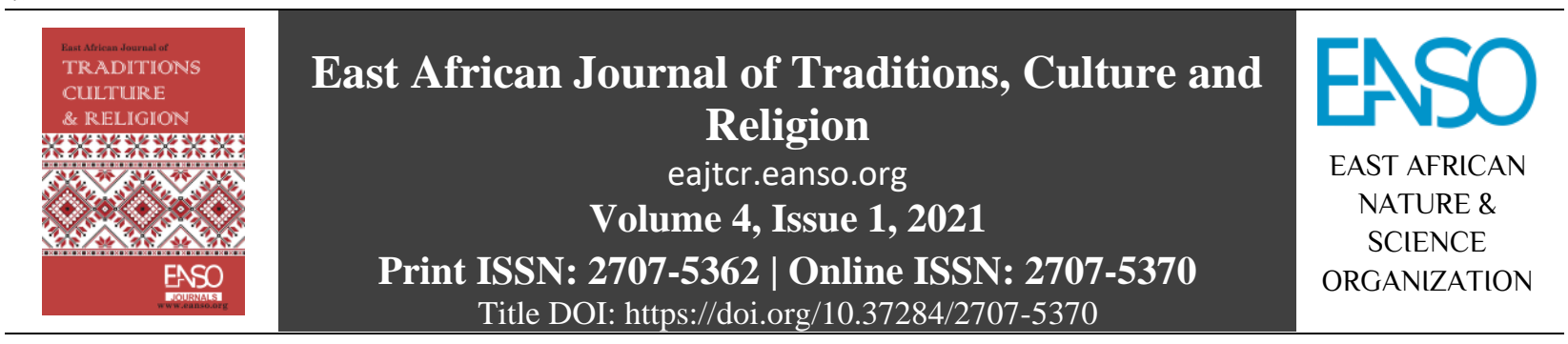

Original Article

\title{
Changing Motivations for Woman-to-Woman Marriages among the Nandi of Kenya.
}

\author{
Emily J. Choge-Kerama, PhD ${ }^{*}$, Miriam C. Rono ${ }^{1}$ \& Jeanette Dickerson-Putman, PhD ${ }^{2}$ \\ ${ }^{1}$ Moi University P. O. Box 3900-30100 Eldoret, Kenya. \\ ${ }^{2}$ Indiana University-Purdue University. \\ *Author for Correspondence Email: baraka_e@yahoo.com
}

Article DOI: https://doi.org/10.37284/eajtcr.4.1.562

\section{Date Published: ABSTRACT}

08 November 2021 In Africa, marriage was only seen to be complete if there were offspring and for that matter, male offspring. In cases of childlessness or bearing of only

Keywords: girls, woman-to-woman marriages were explored as an alternative to siring of a male offspring. An elderly childless lady or one bearing only girl children

Changing Motivations,

Woman-to-Woman

Marriages, Nandi community. would marry a young girl who for one reason or another would be able to get offspring to inherit the name and the property of the older woman. However, in the present situation the practice of woman-to-woman marriage is facing various challenges, health, legal, economic, social and religious implications. In this paper we will look at the past and present status of the practice and then give a summary of the practice in the African continent in general, in Kenya and within the Nandi community in Nandi in particular. We will show how this practice was done in the past as discussed by the ethnographies and we will show some of the changes that have come up in the modern context. We will also use two modern case studies to highlight the challenges that this practice is facing in the modern situation. We will specifically discuss the challenge that this poses to the church and how the church can respond to it. In the end we will provide some theological guidelines to the church even as they provide guidance for the adherents who are faced with challenges on this matter.

\section{APA CITATION}

Choge-Kerama, E. J., Rono, M. C. \& Dickerson-Putman, J. (2021). Changing Motivations for Woman-to-Woman Marriages among the Nandi of Kenya. East African Journal of Traditions, Culture and Religion, 4(1), 46-60. https://doi.org/10.37284/eajtcr.4.1.562

\section{CHICAGO CITATION}

Choge-Kerama, Emily J., Miriam C. Rono \& Jeanette Dickerson-Putman. 2021. "Changing Motivations for Woman-to-Woman Marriages among the Nandi of Kenya”. East African Journal of Traditions, Culture and Religion 4 (1), 46-60. https://doi.org/10.37284/eajtcr.4.1.562.

46 This work is licensed under a Creative Commons Attribution 4.0 International License. 


\section{HARVARD CITATION}

Choge-Kerama, E. J., Rono, M. C. \& Dickerson-Putman, J. (2021) "Changing Motivations for Woman-to-Woman Marriages among the Nandi of Kenya”, East African Journal of Traditions, Culture and Religion, 4(1), pp. 46-60. doi: 10.37284/eajtcr.4.1.562.

\section{IEEE CITATION}

E. J. Choge-Kerama, M. C. Rono \& J. Dickerson-Putman. "Changing Motivations for Woman-to-Woman Marriages among the Nandi of Kenya”, EAJTCR, vol. 4, no. 1, pp. 46-60, Nov. 2021.

\section{MLA CITATION}

Choge-Kerama, Emily J., Miriam C. Rono \& Jeanette Dickerson-Putman. "Changing Motivations for Woman-to-Woman Marriages among the Nandi of Kenya". East African Journal of Traditions, Culture and Religion, Vol. 4, no. 1, Nov. 2021, pp. 46-60, doi:10.37284/eajtcr.4.1.562.

\section{INTRODUCTION}

In Africa, marriage was only seen to be complete if there were offspring and for that matter male offspring. ${ }^{1}$ There was the belief in personal and communal immortality which if there were no children, this was jeopardized. To beat this great tragedy, there were alternatives that were made to remedy such an occurrence. Among many communities in Africa, one way to address childlessness was through woman-to-woman marriages so that an elderly childless lady would marry a young girl who for one reason or another would be able to get offspring to inherit the name and the property of the older woman. Among the Nandi community, there was also the practice known as kitunji toloch (a girl married at home) which happened when a family had only girls born into the family. In such a case, one of the girls would be retained in the home and a genitor would be found for her to sire male offspring. The form of such a union would take the name of the family and the name would be retained. This kind of marriage was also done when a married woman was found to be barren.

However, in the present situation the practice of woman-to-woman marriage is facing various challenges, health, legal, economic, social and religious implications. The girls married into such unions do not carry the same commitment that would have been seen in the past. They are in it for their own gains and interests and if they do not coincide with those of the elderly lady, they do not hesitate to get their own way and they may even neglect the elderly lady. In this paper we will look

\footnotetext{
${ }^{1}$ R. Jean Cardigan, "Woman-to-Woman Marriage: Practices and Benefits in Sub-Saharan." Journal of Comparative Family
}

at the past and present status of the practice and then give a summary of the practice in the African continent in general, in Kenya and within the Nandi community in Nandi in particular. We will show how this practice was done in the past as discussed by the ethnographies and we will show some of the changes that have come up in the modern context. We will also use two modern case studies to highlight the challenges that this practice is facing in the modern situation. We will specifically discuss the challenge that this poses to the church and how the church can respond to it. In the end we will provide some theological guidelines to the church even as they provide guidance for the adherents who are faced with challenges on this matter.

\section{WOMAN-TO-WOMAN MARRIAGE IN AFRICA}

Woman-to-woman marriage is a common practice that occurs throughout the continent of Africa in communities that were both matrilineal and patrilineal. In West Africa, it was common in Dahomey and in Ghana. In Nigeria, it was practised among the Ibo of Eastern Nigeria. One of the characteristics of woman-to-woman marriages was the need for a male heir to bring offspring in a childless marriage; however, the communities in West Africa seemed to have practised this with different motivations. The women, especially among Dahomey and the Ibo were rich and had acquired much wealth through trading, so they sought to increase their household membership by marrying multiple wives. They need not have been barren, and they had sons, but they wanted to

Studies, Vol. 29, No. 1, Comparative Perspectives on Black Family Life: Volume I (Spring 1998), pp. 89-98.

47 | This work is licensed under a Creative Commons Attribution 4.0 International License. 
increase their business empires. ${ }^{2}$ Krige also quotes Herskovits who writes about woman marriage in Dahomey. They are powerful and called "husbands" by their wives. ${ }^{3}$

In Sudan, it was practised among the Nuer and the Dinka. This was mainly done by women who were barren and Krige says, "A barren woman was considered a man and would inherit wealth like the male in the household." She notes, "She is regarded as a man even to the extent that if after her death, her ghost causes sickness to draw attention to her unhappy plight, her brother's son may marry a woman who will bear children to her name. ${ }^{5}$ The children are called after the female ghost as though she were a man, while the brother counts as their paternal uncle 'for his sister has become his brother." "They could marry even up to three wives. A childless widow would also marry and raise children for her dead husband.

In Southern Africa, the practice was common among the matrilineal communities, the Lovedu. Krige notes that among the Lovedu in South Africa, women can acquire property and be able to gain "wives" if they have no sons. ${ }^{7}$ But one of the most interesting practices is giving daughters to the queen for political favours. ${ }^{8}$ Women hold very high positions and a woman is a queen. A woman who was not on good terms with her husband can use the bridewealth gained from the marriage of her daughter to get a wife for herself without the knowledge of the husband. Nowadays, due to urbanization, a son may want to get a wife for himself, but a mother would still marry a girl for him. Some refuse due to modern education and urbanization to carry on this practice. "Once they have been to school, girls today refuse to marry a woman. They are taught by church and school that

\footnotetext{
${ }^{2}$ Eileen Jensen Krige, "Woman-Marriage, with Special Reference to the Lovedu. Its Significance for the Definition of Marriage." Africa: Journal of the International African Institute, Vol. 44, No. 1 (Jan. 1974), 14.

${ }^{3}$ Krige, 15 .

${ }^{4}$ Krige, 12 .

${ }^{5}$ Ibid., 13 .

${ }^{6}$ Ibid.

${ }^{7}$ Ibid., 16.

${ }^{8}$ Ibid.

${ }^{9}$ Ibid., 18.
}

they should choose their own husbands." ${ }^{9}$ A woman may also inherit the "wives" of her father like the son can do the same. A type of woman-to-woman marriage was done among the Lovedu when a woman was barren. Krige calls it a "form of marriage to bolster up an existing marriage to get offspring." ${ }^{10}$ Usually, a daughter of a brother or a sister was given to the family to help raise a child for the barren woman. ${ }^{11}$ Through the institution of woman-to-woman marriage, the queen is linked to various locations and her power is consolidated. Today "Girls who have gone to school refuse to marry a woman."12

Marriage can take widely different forms, even sometimes within the same society, each involving different categories of rights and duties. The sexual relationship between the parties concerned in a marriage is not, as is commonly believed, central to the institution. Marriage may be entered upon by people of the same sex in capacities that have no sexual connotation. Marriage in Africa is concerned largely with ensuring the continuation of groups, with the creation of new social units such as 'house'. ${ }^{13}$ Among the Zulu, woman-to-woman marriage is entered for the reason of a male heir. But the British frowned upon this custom so the male genitor stood in for a husband in the registration of marriage. ${ }^{14}$

Cardigan also writes on woman-to-woman marriage across Africa ${ }^{15}$ notes that woman-to-woman marriage is a tool that upgrades the social and economic position of women in the community. This might mean taking the conceptual role of a man and this increasing the economic benefits to such a union. ${ }^{16}$ She surveys woman-to-woman practices across Africa and gives the main reason for such arrangement; was to alleviate barrenness. Among

\footnotetext{
${ }^{10}$ Ibid., 16.

${ }^{11}$ Ibid.

12 Ibid., 22.

${ }^{13}$ Ibid,34.

${ }^{14}$ Ibid., 17.

15 Jean R. Cadigan, "Woman-to-Woman Marriage: Practices and Benefits in Sub-Saharan Africa." Journal of Comparative Family Studies, Vol. 29, No. 1, Comparative Perspectives on Black Family Life: Volume I (Spring 1998), pp. 89-98.

${ }^{16}$ Cadigan, 91.
} 
the Kamba of Kenya, a barren woman is a disgrace. 17 The husband of the "female" husband is brought in to sire the children but not someone from the outside among the Kamba and the Kalabari. ${ }^{18}$ The motivation is to gain economic benefits from the estate of the husband; otherwise, she risks losing this ${ }^{19}$. Woman-to-woman marriage was a means of acquiring and investing wealth, especially in West African communities that women were involved in trading.

Marrying for a "son" or a daughter is another form that this practice took. Women without sons would marry a daughter in law for the house. ${ }^{20}$ She gives motivations for engaging in such marriage for the "female husband" and the wife and she notes that they all have to benefit. The wives especially because of poverty and lack of economic provision. It legitimizes the children that are born out of wedlock. It also elevates the position of the husband of the female husband. ${ }^{21}$ She also notes, "The apparent decline of woman-to-woman marriage may negatively affect the position of women, particularly barren women who frequently use woman-to-woman to gain the status associated with motherhood." 22

\section{Woman-to-woman Marriage in Kenya}

In Kenya, woman-to-woman marriage was common among the following communities: the Kikuyu, the Kamba, Kuria, Kisii, the Nandi and the Luo. Kareithi notes that Kenya is one country that still practises, recognizes and accepts the customary practice. $^{23}$ A more recent study in 2000 by Njambi and $\mathrm{O}^{\prime} \mathrm{Brien}^{24}$ revisits the practice among the Gikuyu of central Kenya questions the use of the term "female husband" because it introduces gender role conceptions that are foreign to the practice.

\footnotetext{
${ }^{17}$ Ibid.,91.

18 Ibid.

${ }^{19}$ Cadigan.

${ }^{20}$ Ibid.,94.

${ }^{21}$ Ibid.

22 Ibid.,97. See also Nancy Baraza"The Institution of Womanto-Woman Marriage in Kenya: Navigating between Culture and Human Rights." Africa Nazarene University Law Journal (ANULJ) 71 6(2) (2018), 80.

${ }^{23}$ Monica Wanjiku Kareithi, A Historical-legal Analysis of Woman-to-woman Marriage In Kenya. A Ph.D. Thesis presented in the University of Pretoria (2018), 12
}

They use the terms "ahikania" and "ahiki". The same word is used for marriage regardless of whether it is marriage to a man or to a woman. Churches do not approve of this kind of marriage, so they are done according to the traditional customs. $^{25}$ The benefits are not purely economic, social, and emotional ties in these relationships also come into play. ${ }^{26}$ They alert us to the fact that we should not be restricted to narrow motivations such as having a male heir or lack of children:

...The women initiating these marriages pursued
various objectives: companionship to appease
loneliness, to be remembered after death, to have
children to increase the vibrancy of the
household, to fulfil social obligations in
accordance with indigenous spiritual beliefs,
and not least to avoid direct domination by male
partners in a strongly patriarchal society,
including men's control of both the women's
behaviour and household finances. Our study
does not deny the inability to bear children,
inheritance...

They add another motivation. It is also a strategy among the Kikuyu to prevent male relatives from taking land from the female folk. ${ }^{28}$

Among the Kamba, marriage was undertaken mainly to regain heirs for the name of the family to continue. It was a disgrace not to have any children. But in the most recent past, this reason seems to have gone beyond this as Obbo observes that there were cases when women opted to marry a woman because they were disappointed with men who were not "husband material." 29 Some were women who had married but divorced for various reasons but still opted to get into a woman-to-woman marriage. So, one can see that even among the Kamba, it was

\footnotetext{
24 Wairimũ Ngarũiya Njambi and William E. O'Brien, "Revisiting "Woman-Woman Marriage": Notes on Gĩkũyũ Women." NWSA Journal, Vol. 12, No. 1 (Spring, 2000), 1-23

25 Njambi and O'brien, 3.

26 Ibid.,6.

${ }^{27}$ O'brien and Ngaruiya, 9.

${ }^{28}$ Ibid., 11,14.

${ }^{29}$ Christine Obbo, "Dominant Male Ideology and Feminine Options: Three East African Case Studies" Journal of International African Institute, Vol.46. No 4 (1976),374.
} 
not just for reasons of a male heir that practice was done.

Among the Kuria, it was a practice that still goes on to the present. ${ }^{30}$ It was for the reason of getting a male heir and to increase female labour output in the home. The "wife" was also accepted as a daughter in law for the missing male son. ${ }^{31}$ Among the Kisii, a woman who took a wife was seen to be a wise woman lauded for her decision and is not answerable to anyone. ${ }^{32}$ From the above discussion, we note that women in African societies who could not get children had various options open to them. The Nandi community in Kenya also offered these options to women in the past, but in the present, the practice has run into various complications, financial, legal and religious. Before we discuss the practice in the present, we will show how it was done in the past.

\section{Woman-to-woman Marriage among the Nandi in the past}

Though there are various ethnographies about the Nandi from the past, they do not focus on the "woman-to-woman" marriage as does Oboler, who has discussed it in great detail. Oboler notes that it involved post-menopausal women or women of advanced age, those women who could not produce a male heir. ${ }^{33}$ The main purpose of the institution was to produce a male heir. The 'female husband' could be a widow, but she does not have to be. A woman pays the bridewealth for her wife from her house property. Oboler suggests that widows may have more control over their house property. A woman needs a male heir to inherit her house property. Often a higher bridewealth is paid for a woman in a woman/woman marriage because it is not an ideal marriage. Only a small number of women had the resources to be able to marry a woman. This agrees well with the Kuria community where the bride price for such a woman was 16

\footnotetext{
${ }^{30} \mathrm{https}: / /$ www.standardmedia.co.ke/article/2001257316/wherescary-traditions-allow-women-to-marry-women

${ }^{31}$ Nancy Baraza, "The Institution of Woman-to-Woman Marriage in Kenya: Navigating between Culture and Human Rights." Africa Nazarene University Law Journal, 100.

${ }^{32}$ Kareithi, 128.

${ }^{33}$ Regina S. Oboler, "Is the female Husband a Man? Woman/Woman Marriage among the Nandi of Kenya" Ethnology Vol. 19. No 1 (Jan. 1980), 73.
}

cows. ${ }^{34}$ If a woman is still married when she takes a wife, she must suspend sexual relations with her husband. She does not have a sexual relationship with her wife. Female husbands live separate from their wives but nearby. If male husbands are alive, they live separately from them.

The division of labour in woman-to-woman households is similar to that in male-headed households. Female husbands "act more like men". They should attend male initiation, observe kerek rules. Female husbands should take on the formal role of father to their children. They should be the disciplinarian to the children. ${ }^{35} \mathrm{~A}$ small number of woman-to-woman marriages reflect the fact that it is hard to find women who will accept this kind of marriage and it requires house property that can support a bridewealth.

A wife should be hard-working, well-mannered and from a good family. A woman will agree to this type of marriage if she cannot find a male husband. Usually, this is because she is pregnant or already has a child. A woman/woman marriage may seem attractive to the wife because there is less arguing and more freedom. Marrying a woman gives a mother a father for her children and inheritance rights for the children ${ }^{36}$.

In the past, female husbands chose genitors for their wives from their husbands' kin groups. This was meant to be a longstanding relationship. The genitor comes to the wife. In 1980 Oboler said wives insisted on choosing the genitors but claimed they were not promiscuous. They had a longstanding relationship with one genitor. Genitors have no rights in the wife or children. The offspring belong to the clan of the male husband. The usual pattern in woman/woman marriage is one of harmony and mutual respect. Ties of affection can develop in these marriages. The couple gains status in the community through a stable marriage. ${ }^{37}$ These are

\footnotetext{
${ }^{34} \mathrm{https}: / /$ www.standardmedia.co.ke/article/2001257316/wherescary-traditions-allow-women-to-marry-women

${ }^{35}$ Oboler, 75.

${ }^{36}$ Ibid., 76.

${ }^{37}$ Ibid., 79.
} 
the kin terms used in marriage; The female husband refers to her wife as my wife and the children from the union as my children. The wife and children call the female husband kogo; this means grandmother. If the male husband of the female husband is alive, the "wife" may perform non-sex roles for the male husband or the female husband may perform roles for her male husband. ${ }^{38}$

Though this was a practice that was done in the past in the Nandi community, it persists to the present as will be shown by the case studies that will be presented. Some of the important characteristics are maintained, but there are changing motivations that are entering into the institution, as will be shown.

\section{Woman-to-woman Marriage Among the Nandi in the Present: Two Case Studies}

The woman-to-woman marriages still persist among the Nandi. The sources of these materials are results from four oral interviews with two couples in Kesses Division. These interviews were carried out in March and September 2018. This shows us that a few cases of woman-to-woman marriages still persist in Nandi; a case in point is one elderly lady, Tapkurgoi (not her real name) aged 75, from Burnt Forest who was earlier married to Arap Rop (not his real name) aged 85 and now deceased. Tapkurgoi is now married to Grace (Not her real name), aged 36 years old of the Kapsirgoi clan. The marriage between Tapkurgoi and Grace was due to her childlessness after Tapkurgoi miscarried twice and lost one son in his youth hence became childless. The husband, Arap Rop, organized for her to get a younger woman to 'marry' so that "her fire would be lit".

Grace did not go through to "sigroina" (the courting cottage) nor circumcision. ${ }^{39}$ However, she was taught that in the past, there were women who had no children and would look for a relative or a woman with children to 'light a fire' for her in the

\footnotetext{
${ }^{38}$ Ibid., 84.

${ }^{39}$ It was a common practice in the past that girls who were in their adolescent would go to the courtship cottage before they went for circumcision. Here they learned self-discipline and any man who tried to force them into sex was disgraced publicly. This was a signal to us that Grace was of a younger generation when girls stopped going for circumcision and to the courtship cottage.
}

form of marriage. She got married to Grandmother Tapkurgoi without knowing they were related and later realized she was a distant cousin to her grandmother. When asked how she viewed this kind of marriage, she said:

Yes, I accepted since I had four children of my
own out of wedlock and no land, yet
grandmother had land and I saw it as an
opportunity. I saw the land not grandmother
though I sympathized with her barrenness." 40

When asked the name of this kind of relationship and whether she was informed earlier that she was going to marry grandmother, she responded, "It is called kilaal maat (to light a fire) hence I was informed earlier to go and live with her and get children for her lineage." 41

Agnes (not her real name), our second respondent is much older than Grace and she has been working at Moi University as a support staff since 1987. She is married to Taplelei (not her real name), who celebrated her 100 birthday a few days after our interview. ${ }^{42}$ She told us she knew about this type of marriage and its existence when she was in seclusion after her circumcision. She says:

"nobody would tell you when you were younger. We were taught at that time of seclusion after circumcision that this type of marriage is different from the others. It is similar to getting married 'into the house or at home'... a type of marriage where one girl remains at home to continue the lineage of the mother bore girls only. "43

When asked about her circumcision and if there were any teachings during seclusion, Elizabeth confirmed that she did get circumcised in 1980 in Nandi-Hills "Yes, we were taught many things that were valuable in intergenerational relationships." 4

\footnotetext{
${ }^{40}$ Oral interview with Grace on 7/3/2018 at Burnt Forest.

${ }^{41}$ Ibid.

${ }^{42}$ She passed away in December 2019 aged 101.

${ }^{43}$ Oral Interview with Agnes in September 2018 in Kesses.

${ }^{44}$ Ibid.
} 
Do you think these are the teachings that have helped you to maintain respectful relationships with Kogo and other people? "Yes, during circumcision, we were taught that there are things that are taboo (etan), things we should not say to older people, how we should relate to men, not to use abusive words and terms to others. That is the reason I keep respectful relationships. I do not throw insults to others." 45

Agnes told us that Taplelei is her maternal aunt. She also told us how she was chosen by her grandmother to light the "fire" for her barren daughter. She narrates;

Yes, it was my grandmother who told me that she had looked around and she had decided that I was the one to take care of the daughter. She said that she had seen that if it was anybody else, this grandmother would die early, but if it was me, I could take care of her till she was blessed with a family line (lit. her fire would burn). So, I listened to her and felt my heart burning within me, wondering why I had been chosen. I told them if the parents accepted, I would not turn back on their word. So, I accepted, and we have stayed with this grandmother since 1974 April. ${ }^{46}$

Grace gave birth after class eight and could not proceed with her studies due to financial constraints. When asked if the father of the child proposed to marry her, she said:

Yes, he did, but my father was hesitant because he was a drunkard and a long-distance lorry driver. He doubted him because he had several other women. I gave birth to three children and when I was coming, I was expecting another child. ${ }^{47}$

Tapkurgoi points out that "when grandfather Arap Rop was crying over my "fire", a relative of Grace who lives around heard and started looking for this woman, the sister brought her to come and see my place. Later my husband went to see her. Grace's father accepted the proposal and she had no option." ${ }^{48}$ Grandfather was ready to do anything to

\footnotetext{
45 Ibid.

46 Ibid.

${ }^{47}$ Ibid.
}

make Tapkurgoi happy, so he paid dowry for the woman in order to continue her lineage by lighting the fire for her. This was not a problem for him because he had already married a second wife who bore him children; hence his lineage was already continuing.

The suitable choice for this kind of arrangement was a woman who had children at home and had no suitor. For this specific case, Grace had three children from the same father and was expecting the fourth one. On arrival in her new marital home, she feared to present all three children. Arap Rop and the brother went for the engagement and when she came, she had two children. When asked where the others were, she said they were at home for tuition. Later she confessed that she had feared coming with them. However, this should not have been the case because the family of Tapkurgoi had accepted her with all the children.

Grandmother Tapkurgoi's perception of this kind of marriage was positive she confirms:

I accepted because I wanted my "fire" lit. I stopped receiving periods at the age of forty. So, when I got this girl, I was happy that she lights the fire for me'. I knew I was old and could not adopt a child. This one became better. There were many women to choose from, but my cowife did not want me to succeed and barred them from marrying me. ${ }^{49}$

It should be noted that in the past, a marriage ceremony was conducted, but in the present, this has changed. Today Tapkurgoi points out that traditional marriage is no longer conducted. In her case, when the bride price had been paid, the husband and brother her in-law went to bring Grace to her home, but she stayed behind then later followed them. According to Tapkurgoi, it was fine and there was no marriage ceremony.

Tapkurgoi says, "there are neither specific guidelines nor taboos on this type of marriage", 50 but she told her to behave well. When she gave birth, I did not mind "after all, I had no people.

\footnotetext{
${ }^{48}$ Oral Interview with Tapkurgoi, the female husband of Grace on 17/3/2018 at Burnt Forest.

${ }^{49}$ Ibid.

${ }^{50}$ Ibid.
} 
However, I told her to be careful to select whomever she gets the children from so as not to contract diseases." ${ }^{51}$ What she doubts is how she gives birth to all the children having cautioned her earlier on the consequences of multiple relationships and the number of children, but she seems not to have heeded her instructions.

Today changes have taken place and the husband does not choose whoever sires the children for the married lady. Tapkurgoi confirms this when asked if she knows the father of her children. "No, I don't know it seems they don't come from around. She visits her home and comes back pregnant." 52 Unlike in the past whereby a relative was identified for her. Tapkurgoi does not see any man around the homestead. However, this is not her concern but cautions the "wife" to take care lest she contracts HIV and leaves the children desolate now that she is old.

When respondent Agnes was asked if grandmother Taplelei assigned her father to her children, she said, "no, she did not, I chose my own; those days of being assigned someone are gone. If you are assigned to somebody, they become like a husband and they can even start beating you. In fact, I had different people father my six children, among whom one passed on. My mother told me that once I have accepted this kind of marriage, I go ahead and find someone to give me children." 53

The other difference from the past is that when the grandmother or the female husband gets married, she still stays with the husband, unlike in the past where she was separated totally. They did not, however, relate sexually though, Tapkurgoi confided to us that the husband was still young but was sexually inactive. This specific couple had given birth earlier. According to her, this marriage to Agnes did not change her relationship with the husband and they related quite well as husband and wife.

\footnotetext{
${ }^{51}$ Ibid.

${ }^{52}$ Ibid.

${ }^{53}$ Oral Interview with Agnes.

${ }^{54}$ Oral interview with Tapkurgoi.
}

Today the challenges of this kind of marriage to both the "wife" and "husband" seem more than it was in the past. When it comes to taking care of the "husband", the wife does not take good care as is expected. In the case of Grace, she would not let her children take care of grandmother Tapkurgoi, who laments, "when the girl finishes form four, she would rather stay at her home than to come here and assist me. I cautioned her upon hearing that and she has stopped talking badly" says, grandmother.$^{54}$ But on her part, Tapkurgoi points out that she has been taking good care of the 'wife', but on the other hand, she notes how negative Grace has become, "she seems to have changed since she gave birth and I do not know why she has changed, yet I have been taking care of her." 55 When asked whether she takes care of grandmother, Grace responds on the contrary:

"No, I do not wash her clothes for she does not accept; she does so and even cooks for herself because I still have a small baby; hence she avoids being contaminated with postpartum taboos (kerek). Ee....each of us has a separate home, but children are free to stay in both. However, I could assist her when she is old. She is the one taking care of me now that I gave birth recently. " 56

Grace further notes, "Our relationship is that of mother and child grandmother relates to me well, she calls me her 'children' (lakwani) she doesn't take me for a 'wife'." 57 When respondent Agnes was asked how she related with "her husband," Agnes said, "It is good... We get on very well.".58 We actually observed that Agnes treated the grandmother in a warm and pleasant way than the way we saw with the other couple.

The children of Grace are also a nuisance though they relate well with grandmother; when it comes to matters regarding discipline, they seem not to listen to their 'father'. Tapkurgoi noted, "We relate well, I caution them, but they do not listen to me. At times they disappear from home without herding the

\footnotetext{
${ }^{55}$ Ibid.

${ }^{56}$ Interview with Grace.

${ }^{57}$ Ibid. Our observation and further interview with Tapkurgoi showed that the relationship between the two was not cordial.

${ }^{58}$ Interview with Agnes.
} 
animals. For example, today, they left the cows unattended." 59

The disciplining of the children is the mandate of the 'father' as she says:

I am the one who does so, I call them and talk to them and I tell the mother to caution them because I do not want any quarrels and do not want the children to be idle. She has also matured after giving birth to all these children. I had been staying with one of the boys but when the mother went to visit her home he also left. I have constructed a separate house for her so that she lives with the children. ${ }^{60}$

Tapkurgoi further expresses her frustration, "I love the children, but they are arrogant but "what do I do? In fact, I want the boy to come back and stay with me."61 For the elderly "husband", she expects the children to respect her just like any other husband.

From the findings, it is evident that this kind of marriage is faced with financial constraints; the elderly "husbands" have very little to offer; Tapkurgoi says, "I have nothing to give her; we only have one cow. In fact, she has to weed people's maize to get money. I sometimes buy seeds for her to plant. However, last year she went around without planting any maize." ${ }^{2}$ The wife claims she normally sells maize to get our subsistence, but the maize is getting depleted. The children attend the nearest primary school and the government has said there are no payments, but they keep on asking for money. ${ }^{63}$

Grace says further, "Grandmother Tapkurgoi supports me a little when it comes to digging. I have to work harder and dig a larger piece, she has her own garden and I send the children to assist her. She also assists me financially when I am stuck, especially when planting and I have no seeds."64

When asked who will inherit her property, Taplelei says, "Why not? It belongs to them. They are my

\footnotetext{
${ }^{59}$ Interview with Tapkurgoi.

${ }^{60}$ Ibid.

${ }^{61}$ Ibid.

${ }^{62}$ Ibid.

${ }^{63}$ Interview with Grace.
}

children". ${ }^{65}$ The wife Agnes tells us she bought the pieces of land she lives in herself when she got employed at Moi University in 1987 and another one that the 'husband' kogo Taplelei bought not far from where she lives. Grandmother (kogo Taplelei) had been married long ago and must be having her land where the co-wife resides, but Agnes says, "it is a distance from where she lives and I had not inquired about that but I believe it is there because that is where she was married. Grandfather passed on, but his older wife is still alive, if the land is there, she can claim it, Yes we can claim it now that her fire has been lit and she has the children to inherit her." 66 When asked if Kogo has land in Kesses she pointed out "No I came to Kesses to live with Kogo because she was staying in the house of a kinsman who had gone to Maasai land, so she came to take care of that house." 67

One of the respondents points out that this kind of marriage of being married by a woman is similar to 'being married into the home'; however, it is different from what it was in the past. The female husbands do not mind the societal perception of this kind of marriage. When asked if people appreciate this kind of marriage, grandmother Tapkurgoi says:

No, I have not heard anybody talking about me and even if they do, I don't care". To me, this marriage is prestigious, and I have benefited. I have a 'fire lit' even if people talk. For me, she lights my fire, people know I have children and I am respected. She is here to light my fire; if grandfather had passed on without looking for her then I would have suffered without anybody to care for $m e .^{68}$

For the married lady, this kind of marriage is beneficial as she then belongs to somebody and her children too. She is then respected hence belonging to a home. Her children get a lineage and are named after the ancestors of her marital home. "Grace

\footnotetext{
${ }^{64}$ Ibid.

${ }^{65}$ Interview with Taplelei.

${ }^{66}$ Interview with Agnes.

${ }^{67}$ Ibid.

${ }^{68}$ Interview with Tapkurgoi.
}

54 | This work is licensed under a Creative Commons Attribution 4.0 International License. 
proudly told us, "My children are named after Kapmaraba, where I am married." 69

Respondent Agnes acknowledges this kind of marriage is good and that she has lived with Kogo Taplelei well. "I control my behaviour and I respect Kogo, so I find no problem."70 When asked if she sees this as preferable to not getting married or being married to a man and not being happy in the marriage, she responds, "yes, I see this as very good for me. I have had a good life."71

However, she notes some challenges she encounters "This life is ok, but I encounter the challenges when I deal with issues of the land; I would have preferred someone who can act as an "umbrella", meaning they are there shielding me."72 When asked if sometimes men might mistreat her because she does not have any man as a protector, Agnes says she has not experienced that though it is possible that others could easily take advantage of her. "But for me, I have stood my ground and I have not experienced any ridicule or mistreatment from the male folk. But if you are not strict, some can follow you." ${ }^{, 73}$

Agnes also acknowledges that there are those men who would want to come and live in the house "yes, there are such kinds, but KogoTaplelei helped me in this, she told me, "If you bring them into the house, they will come in and become your husband and they will start beating you." So, the warning was to keep them outside the home "Seek what you want from them, but then leave them out there."

This kind of marriage has its own challenges, though "Now that I am old, I can't fend for them as expected. Another challenge that I face is that of the children who misbehave, and I have to correct them." 75

To Tapkurgoi, the large number of children is not an issue though she fears how she will provide for all their needs. She says: -

\footnotetext{
${ }^{69}$ Interview with Grace. Kapmaraba is the lineage of the Tapkurgoi's husband.

${ }^{70}$ Agnes.

71 Ibid.

72 Ibid.

73 Ibid.
}

I do not mind if she should have stopped at four children, but she could not; we cannot sell them, they are mine. Eee... this reminds me of an incident when I went to a certain family Kapchemei just there and a lady friend approached me asking if I could assist her with one of the younger children because she had nobody in the house. I refused, saying, let us just suffer rather than distribute the children to other people. If I have anything, I would rather give to them rather than throw to dogs. ${ }^{76}$

According to Agnes, the future of this kind of marriage depends on personal choices; to date, the problem of barrenness persists and there are also the homes where girls only are born. However, due to modernity, the girls of today will not accept being married 'into the home'. A neighbour of hers called Ursula, whose parents bore girls only was asked to be married 'into the home', but she refused and got married but came back after she had four children. Her mother had already married another girl called Mary. She came back home, and no one could turn her away, so she came to be the second wife of Kogo and the co-wife of Mary. ${ }^{77}$

Grandmother Tapkurgoi says the future is bright because of "her people," the children, "even if I have anything, it won't get lost. The advice I would give to a lady who has no children is for her to try her luck (koset). If she gets a single lady with children to marry, well and good, but if she adopts a child, it is fine." 78

Respondent Agnes, one of the 'wife's' interviewed, said,

This kind of marriage is different from one with a male husband and female wife because it is only Kogo Taplelei who controls my life. The do's and don'ts as instructed by a female husband are just the same as those of the other home. Yes, it matters how each individual responds to it. If you take it positively and the

\footnotetext{
${ }^{74}$ Ibid.

${ }^{75}$ Interview with Tapkurgoi.

${ }^{76}$ Ibid.

${ }^{77}$ Interview with Agnes.

${ }^{78}$ Interview with Tapkurgoi.
} 
way it should be you live very well and it is good. But it depends on how you respond to it. The younger generation would respond differently to this kind of marriage. It is very different now. Some forget they are married, and they take the law into their hands; hence they abandon the home and children because they see it as the freedom to do what they like. But as for me, I took it the way it was. I accepted my situation and lived with Kogo Taplelei in a good way. ${ }^{79}$

A when asked was why the children of today are not ready to accept this kind of marriage at first? She responded, "The children of today are not ready to accept this kind of marriage because they want to be married by a husband and will not accept to stay the way we did. They do not accept to live the way we did. They first go, then they come back. I have seen many who have done this. Many have gone to be married, but when the sweetness of the husband has gone, then they go back home to their parents." 80

One of the challenges of this kind of marriage is economic stability. Agnes, our respondent's "wife", decided to look for a job outside the home, but the "husband" did not like it because she feared that she would run away with a man. This is how she convinced her,

So, I asked Kogo Taplelei, do you have ten acres of land, many cows, sheep and goats that I will be taking care of? But if you do not have, then I do not have anything to take care of but go to the University to look for a job. I asked her how we would take care of the children we were raised without any resources. I told her clearly that the Luhya lemek I had seen in Nandi-Hills were the same as those that were in the University and if I had not run away with them earlier then it would not happen now. They would not move me unless they used love potions. If they did that, then I would be powerless to follow. You know they can use that on dogs, and they will follow. Otherwise, I did not see why this should bother. Yes, this changed Kogo... It was enough to calm her down. From that time, she looked after the children as I went to work till I got the last born. Whenever I got the babies, I would not bother her with the little one, but I would employ a maid till the babies would be about 9 months old then after that I would dismiss the maid and she would take over the care of the children. Then I would wait till I got another child and the same would happen... Grandmother was very valuable and very crucial in raising the children. ${ }^{81}$

Agnes concluded her interview by giving an invitation to the celebration to thank God for Kogo's life. She said proudly, "We are doing a Birthday celebration for her getting to be 100 years old. If you can make it, please come and celebrate with us." ${ }^{\prime 2}$

\section{Challenges that this Practice Presents}

In modern times this practice though it performed a functional role in the community in Kenya and all the other African communities it has met several challenges due to the changing environment. The challenges are related to colonialism and globalization in the modern days and these contribute to the changing motivations. The financial challenge seems to be the most pressing need that is driving the girls into entering into these unions. They realize that with no education and no modern skills to survive with children without being married to a man, this is an option that is open to them. Though in the past woman-to-woman marriages among the Nandi attracted girls that had children outside wedlock, this is more a pressing need, especially in the modern situation because this seems to be the only option that is open to them. Through the literature and even with our respondents, it seems that this institution does not seem to attract girls who have other options open to them.

In both cases, the two ladies had children before wedlock. In the case of Grace, she had three children and was expecting the fourth one and there were no prospects of being married by the father of the children. So, she was in a desperate situation. The prospects of getting a home for her children motivated her and she did not seem to care much to meet the needs of the barren lady who had taken her into her home. It looked like if she had other options, she would not have stayed in the marriage.

\footnotetext{
${ }^{81}$ Interview with Agnes.

${ }^{82}$ Ibid.
}

56 | This work is licensed under a Creative Commons Attribution 4.0 International License. 
Our second case had a more cordial relationship and she seemed to care genuinely for the elderly lady. She had the opportunity to opt-out of the marriage when she acquired a job at Moi University, but she chose to stay with the lady to date. ${ }^{83}$ The financial challenges are compounded in these marriages; the two ladies do not have a stable source of income which is the case for Grace and Tapkurgoi. This is made worse by the number of children in the marriage. This is also a concern that has been observed among the Kuria, where this practice is rampant. ${ }^{84}$

Along with this challenge is the fact that in the modern situation, the rules do not seem to be clear as what guided the choice of the genitors. Previously the genitor was chosen by the "female" husband and most likely from the lineage of the husband. But our respondents confirmed that they are free to choose their own genitors and sometimes they are multiple ones. In this present day of HIV and AIDS, this becomes a very serious health risk. In a research done by Singoei and Choge confirm that the practice "was meant to safeguard the interests of the barren woman but it has become a place for unlicensed prostitution a set up for sexual freedom. This becomes dangerous during this time of HIV/AIDS." ${ }^{85}$

Another challenge that this practice faces in the Kenyan situation is its legal standing. According to the Kenyan constitution, marriage is between a man and a woman. This was clearly articulated in the Kenyan constitution 2010 because of the global debate on the homosexual and lesbian challenge. Kareithi notes that though the legal standing of this type of marriage is at stake, what has been protected is that the same constitution also protects cultural rights. This institution is also well recognized as a customary practice with a clear standing as the cases she cites shows where respondents have tried to get out of the practice shows and if there was bride price

\footnotetext{
${ }^{83}$ In our discussions later as to what made the relationships different between the two couples we noted that Grace was of a younger generation and she was motivated more by her need to find a home for her children rather than care and commitment to the elderly lady. However, Agnes seemed to care for the grandmother who married her.

${ }^{84} \mathrm{https}$ ://www.standardmedia.co.ke/article/2001257316/wherescary-traditions-allow-women-to-marry-women
}

paid and evidence that such a marriage existed then the case is ruled in favour of the "wife" and the children in the marriage.

The other challenge that this practice faces is the acceptance by the religious institutions, especially the church. In the research by Njambi and O'Brien, they note it is not accepted by the church though, so those who perform this practice do it outside the church. ${ }^{86}$ In our two case studies, the two couples are members of the church, but there is no theological reflection that has been done so far to address the issue of barrenness and the attendant implications of such a situation in life this is what we will do in the next section.

\section{Theological Reflections and Guidelines for this Practice}

Woman-to-woman marriage among the Nandi is meant to alleviate the situation of barrenness and the lack of a male heir in the family. However, the problem of barrenness is the most acute because in the modern situation if there are girl children in the home it is not impossible even to take the children of one of the girls to be an heir of the home and nowadays girl children are accepted as heirs in the home. In the new Kenyan Constitution, girls are also expected to inherit from their parents.

The Nandi culture is similar to the Jewish culture in the Old Testament in that barrenness was frowned upon and not having children was seen as a curse so that those who did not have children did not have much standing in the community. In the Old Testament, we have Sarah the wife of Abraham ${ }^{87}$ and Hannah, the wife of Elkana. In both cases, they felt taunted because of their state in life. In the case of Hannah, ${ }^{88}$ Elkanah tried to make up for his wife by giving her double portions of the offerings and encouraging her, but it was very difficult for her to cope with the taunts of her co-wife. Hannah, a

\footnotetext{
${ }^{85}$ Rebecca Singoei and Emily J. Choge, "Nandi Traditional 'Woman to Woman' Marriages and their effect on the Spread of HIV and AIDS" in Theologies and Cultures: Volume IX No.2. December 2011: 10.

${ }^{86}$ Njambi and O'Brien, 3.

${ }^{87}$ Genesis 12 .

88 I Samuel 1 and 2.
} 
barren woman, eventually prayed very bitterly to God and God answered her prayer by giving her Samuel whom she dedicated to serving God under Eli. Later God blessed her with other children.

In the case of Sarah, she got her slave girl Hagar to sleep with her husband Abraham and she got Ishmael but there was a great disagreement with Sarah, especially when Isaac was born and Hagar was sent away to the wilderness with her son. ${ }^{89}$ These two examples show that bareness was a source of conflict and disagreement in the family in ancient times and various kinds of solutions were sought. Among the Nandi, the institution of womanto-woman marriage was established for this reason. However, it has brought challenges in the modern situation to the couples that do not have children. Marriage in the Christian tradition is supposed to be between one man and one woman. A man cannot marry a second wife as it was in the past to relieve this kind of situation and the woman-to-woman marriage for a barren woman is not acceptable. Any other affairs that a woman in this kind of relationship engages in is supposed to be seen as adulterous or illicit sexual relationships. The question is what the options for married ladies who have no children are? They can opt to go for expensive fertility treatment which is very exorbitant. It is beyond the reach of ordinary Kenyans.

The other option is to adopt children, and this is the most accessible. It was also a common practice among the Nandi that when a woman was barren, she could get a child to adopt from the children who were born out of wedlock (sarbuch). So, this was common. It was also a practice that there seemed to have been many barren women among the Nandi, but there were children that were "bought" from among the Luhyia, the neighbours from Western Kenya. Nowadays, it is possible to arrange for adoption through the Child Welfare Society, but one has to fulfil some legal requirements, for example, one has to be younger than 65 years of age and one has to have some economic means to be able to take care of the babies and to give them the basic necessities of life. If this is strictly followed, the case of those we have interviewed would not be able

\footnotetext{
${ }^{89}$ Genesis 16.

${ }^{90}$ Interview with Agnes.
}

to qualify or comply with these legal requirements though this would be the best way to go, as our respondents showed us. When we asked if they would recommend what they did to others, they seemed to prefer the option of adoption. One of the respondents pointed out that there are various examples in their neighbourhood who have adopted children and these children are doing very well. "There is a lady called Salina who has three children adopted and another Goretti who has two sons and Jane too has two sons all adopted. This has become the best way to get children," says Agnes. ${ }^{90}$

The issue of barrenness is a very thorny theological issue in the modern situation. The modern technological interventions may be out of reach to those from the lower economic bracket and the option of adoption should be made more accessible to our families. However, there is still a need for much teaching and advocacy in our churches for many who may choose to go the alternative of adoption. For many, the prejudice against adoption should be dispelled in our communities. Many feel they should try every means possible to get their own children because they will feel more connected with their blood and kin. However, adoption has rich theological implications that are within the roots of the Christian faith. We have been adopted by God into his family. ${ }^{91} \mathrm{We}$ do not deserve to be adopted, but we have been given the privilege through the blood of Christ to be adopted, so as Christians, we should understand this concept very clearly. A biological child will not mean more than the child you raised up as your own because the ties of upbringing and socializing are also very strong. In our towns and villages, there are many children that are abandoned, and we should give them an opportunity of finding a home by giving them a place to build the ties of home and the family.

Another word for the church is that there is a need to support women who are in "woman-to-woman" marriages. They should be given the opportunity to share their status in life and be accepted and supported the way they are. One of our respondents, who is a "wife", told us that she has support in her church though it was not clear what support she receives. ${ }^{92}$ This should be the case because such

\footnotetext{
${ }^{91}$ Romans 8:15; Galatians 4:5-8.

92 Interview with Grace.
} 
women face many challenges in their lives, as pointed above. The church should follow the advice that Paul gave to the Corinthians "Was anyone called while circumcised? Let him not be uncircumcised. Was he called while uncircumcised? Let him not be circumcised." $" 93$ A positive role this practice plays is the gift of companionship for elderly women. One thing that we noticed from the second couple in our case study is that she took care of her "husband" grandmother very well and gave her the respect that she deserved. The other couple were not experiencing the best of the relationships and it seemed to us that if she could have found another way out, she would get out of the union fast. There is a need to teach such kinds of ladies the importance of reciprocity. For them to know that just as they have been taken care of by the grandmother, then they should also return a hand and respond positively. This practice has also protected the rights of children that would otherwise not have a home. If there are such people in our churches, we should also take care of them and support them to follow Christ in the situation that they find themselves in.

\section{CONCLUSION}

Woman-to-woman marriage among the Nandi has played a great role and function in the community in taking care of those who are childless and providing companionship for those who would be vulnerable; the women, the old and the children who have no specific support find a home in this kind of marriage. Members of the church who are charged to take care of "the least of these" should be in the forefront to minimize abuses of human rights in the case where the younger women might exploit the older ones and not treat them well. They need to intervene to give the message of salvation so that the ladies gain more self-control in taking care of the children they have got and also in curbing promiscuous behaviour that might lead to more sexually transmitted infections endangering their lives and those of the children. The practice itself might die a natural death if many are not ready to enter into it when they have gained education and financial stability in the modern situation. However, those ladies in these unions are still with us so there is a need to bring the ladies together for moral support with others and provide for incomegenerating skills so that they can help their families. Barrenness will also still be with us, so the church can form groups of ministries to reach such ladies and provide the knowledge and avenues for them to adopt or foster children who need care and support. Thus, cultural practices that played a great functional role in the community should not just be condemned wholesale without providing relevant alternatives for it.

\section{BIBLIOGRAPHY}

Amadiume, Ifi. Male daughters and female Husband: Gender and Sex in An African Society. Zed Books, 1987.

Baraza, Nancy. "The Institution of Woman-toWoman Marriage in Kenya: Navigating between Culture and Human Rights." Africa Nazarene University Law Journal (ANULJ) 71 6(2) 2018: 71-91.

Cadigan, R. Jean. "Woman-to-Woman Marriage: Practices and Benefits in Sub-Saharan Africa." Journal of Comparative Family Studies, Vol. 29, No. 1, Comparative Perspectives on Black Family Life: Volume I (Spring 1998), pp. 89-98.

Kareithi, Monica Wanjiku. A Historical-legal Analysis of Woman-to-woman Marriage in Kenya. A Phd Thesis presented in the University of Pretoria 6th February 2018.

Krige, Eileen Jensen. "Woman-Marriage, with Special Reference to the Lovedu. Its Significance for the Definition of Marriage. "Africa: Journal of the International African Institute, Vol. 44, No. 1 (1974), 11-37.

Langley, Myrtle S. The Nandi of Kenya: Life Crisis Rituals in a Period of Change. New York: St. Martin's Press, 1979.

Meier, Barbara. "Doglientiri”: "An Institutionalised Relationship between Women among the Bulsa of Northern Ghana." Journal of the International African Institute, Vol. 69, No. 1 (1999), 87-107.

${ }^{93}$ I Corinthians 7:18-24.

59 | This work is licensed under a Creative Commons Attribution 4.0 International License. 
Njambi, Wairimũ Ngarũiya and William E. O’Brien. "Revisiting "Woman-Woman Marriage": Notes on Gĩkũyũ Women." NWSA Journal, Vol. 12, No. 1 (Spring, 2000), 1-23.

Obbo, Christine. "Dominant Male Ideology and Female Options: Three East African Case Studies." Journal of the International African Institute, Vol. 46, No. 4 (1976), pp. 371-389.

Oboler, Regine S. "Is the Female Husband a Man? Woman/Woman Marriage among the Nandi of Kenya." Ethnology. Vol.19. No. 1 (Jan. 1980): 69-88.

Women, Power and Economic Change: The Nandi of Kenya. Stanford: Stanford University Press, 1985.

Ojwang, Jackton B. and Emily Nyiva Kinama. Woman-to-Woman Marriage: A Cultural Paradox in Contemporary Africa's Constitutional Profile, Verfassung und Recht in Übersee / Law and Politics in Africa, Asia and LatinAmerica, Vol. 47, No. 4 (2014), 412-433.

Singoei, Rebecca and Emily J. Choge. "Nandi Traditional 'Woman-to-woman' Marriages and their effect on the Spread of HIV and AIDS" in Theologies and Cultures: Volume IX No.2. December 2011: 59-74 